\section{The Formation of Stable Columns of Liquids.}

WHEN a liquid of slightly greater density than water is poured into a shallow layer of the latter, it is often possible to produce the formation shown in the accompanying photograph, in which the heavier liquid appears as a column of curved outline, stretched by its own weight, and hanging from the surface of the water. By performing the experiment in the following manner, the production of the column is rendered easy and certain. A test-tube of the dimensions shown in the photograph, preferably furnished with a foot, is filled to about one half the height of the hemispherical end with water, and 5 to 1o c.c. of acetoacetic ether are then added. Usually, the formation of the column is automatic; if it should fail to form the contents should be shaken up, and the test-tube allowed to stand for a short time, when the liquids will settle as shown. Water globules entangled in the aceto-acetic ether may be removed by drawing to the side with a wire.

If the original layer of

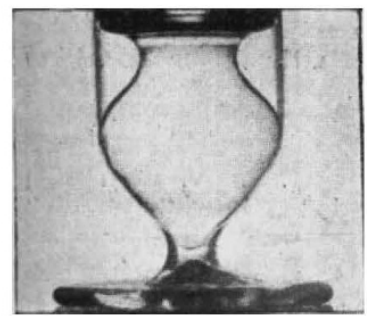

water be too deep, the column will break at its narrowest part, and the same occurs if water be poured gradually into the tube after the column has formed. By varying the width of the vessel, a great variety of shapes may be obtained, all of which are perfectly stable. The water is in all cases displaced from the lower part of the vessel, and bounds the sides of the column of heavier liquid. Similar results may be obtained with aniline, orthotoluidine, butyl benzoate, and some other liquids; but in these instances the manipulation is rather more difficult, owing to the tendency to break up into separate globules. By placing the test-tube in a flatsided vessel and surrounding with water, the column may be projected on a screen, thus furnishing an interesting lecture experiment on the subject of surface tension.

Chas. R. Darling.

\section{THE CORONATION.}

FROM the point of view of social psychology to-day's great ceremony may be said to bind the English people and the present interests of the British Empire. From the point of view of individual psychology it may be regarded as a symbolic elevation of human personality to its highest power.

It is an interesting problem for the sociologist how far a given social ceremony succeeds in realising a modern content in an ancient form. The relation of form and content in social ceremonies and institutions alike is analogous to that of structure and function in organisms. But the inertia of social forms is far greater than that of organic structures, for in the case of the latter there is neither sentiment nor tradition to assist survival.

The development of the ceremony of crowning from Greek and Roman times is clear, but the origins of the crown-symbol itself are still obscure. Outside the sphere of classical, antiquity its use is rare. But within it, as in mediæval and modern Europe, the crown is, next to the King, the central feature of coronation. Not only in popular language, but in legal phraseology, it is a synonym for the kingly office itself. It has, in fact, long ago superseded unction as the central element of royal investiture, making the recipient a king rather than a priest.

The crown of the kings of Egypt was, like regalia generally, considered divine. Kings of the Yorubas NO. 2173 , VOL. 86$]$ sacrifice sheep to their own crowns. In South Celebes it is the regalia that reign; the king is but their representative. If we attempt to penetrate to the strata of early custom which preceded the Greek and Roman kingly crown, the Athenian crowns which were given, just as ribbons of the Legion of Honour are given, the Roman crowns corresponding to the Victoria Cross and similar honours, the Greek wreaths of sacred leaves won in the games, and even the oak chaplet of the early Roman kings identifying them with the oak-god; we may follow some such line as the following. Like unction, crowning had its origin in personal decoration or accoutrement. Savage chiefs are sometimes invested with a girdle. Just as ankle and wrist straps and the like are frequently worn by rude peoples for the practical purpose of protecting the joints and ligaments, and afterwards attract superstitious ideas, such as the idea that they prevent the soul from escaping, so it may have been with the head-band or head-dress, originally used for protection or for confining the hair. The brain being the crown of the human organism, the head has always received honour. From this point of view the crown is the one royal symbol likely to be retained by enlightened peoples, who for various reasons retain kingship.

Coronations in other latitudes are instructive. Investiture with a special or sacred dress is frequently the main feature. The king-elect of the Aztecs went in procession to the temple. Here, after paying homage to the god, he was anointed over the whole of the body by the high priest, and sprinkled with holy water. The unguent was a black oil of rubber. $\mathrm{He}$ was then clothed in ceremonial robes, and about his neck was hung a gourd containing remedies against sorcery, disease, and treason. Hindu coronations took the form of a baptism or an unction. Eighteen ingredients were required for the holy water, one being the water of the sacred river Sarasvati. After a preliminary sprinkling, the king received a bow and arrows, with which he symbolically conquered the four quarters of heaven and earth. Then, seated on a tiger-skin, facing the east, he received the holy water in a shower from a rose-head of gold. Four officiators poured it. Many prayers were recited meanwhile, some "to enable him to discharge his duties," others to the "divine quickeners"; others stated that he was being consecrated by the gods, and being filled with divine force. Vigour and vitality, royal and priestly dignity, were contained in the ingredients of the holy water. His head was then adorned with stalks of holy grass and ears of corn. At the end he quaffed a draught of the sacred soma. His hair was not to be cut for a year after the ceremony. In modern times a Rajput raja is anointed with sandal-paste and rose-water, and the priest marks his forehead with the sacred Tika srmbol. When the raja of the Bhuiyas is consecrated, a chief winds a flexible creeper round his head-dress to signify that he is "Lord of the forest."

Ellis describes the installation of Tahitian kings. The king bathed, and was then ceremonially struck by the priest with a sacred branch. $\mathrm{He}$ was then girded with a sacred girdle of red feathers, which rendered him divine. In old Siam the king was placed under the seventiered umbrella, the great symbol of royalty. A crown and a collar of diamonds were placed unon him, and he received a golden tube containing his namie. In old China the king (like Plato's philosopher-kings) deprecated his elevation, declaring himself to be unworthy. No crown was used: the king was seated upon the throne of the Nine Heavens. In Abyssinia, that most curious pioneer of Christian kingdoms, there 
was a pretiy piece of symbolism. The ling rode on horseback, to find his way barred by a company of girls holding a barrier consisting of a cord of crimson silk. They plied him with the question: Who are you? Then, after an exhibition of horsemanship, the ling severed the barrier with his sword. The priests then intervened, anointed, crowned, and incensed him. It was, no doubt, at the same period that Ptolemy Philadelphus of Egypt reduced crowning to an absurdity. At his coronation, Athenæus tells us, three thousand two hundred crowns of gold were carried in procession, and one of these was a hundred and twenty feet in circumference.

Our own ceremony is a wonderful mosaic of survivals. Its main features are the recognition of the king by the people; the oath of good government; the anointing; the delivery of the regalia; the imposition of the crown; the delivery of "the most valuable thing that this world affords," the Bible; the enthroning; the reception of homage. Among the regalia the antiquary may miss "the hand of justice" of the emperors of the Holy Roman Empire. The most ancient feature, the unction, of course, derives from Hebrew ritual, as the crowning from Roman. The combination of the two marlss the combination of spiritual and temporal power, and is a curious echo of "primitive" kingship, when the monarch possessed both material authority and supernatural mana, and was both president and priest. Unction in its evolution always shows a connection with spiritual ideas; the vehicle is itself a source of life, and, when consecrated, inspires the recipient. But its ultimate origin is the use of oil as part of the festal garb. At one end of the scale we have the Australian medicine-man "singing" a charm of power into a magic ointment; at the other Plato conceives the fancy that the Soul of the Universe was impressed upon material nature by the Creator as an unction in the form of a cross.

Ta the student of man it is interesting to observe that all these elements of the ceremony except the "recognition," have only lost their original magical import, and become symbolic, within the last eight or nine hundred years. $\mathrm{He}$ may ask himself whether the imagination of the people really accepts unction as expressive of modern thought and modern life; whether there is not too much "survival " in the whole ceremony to enable it to retain any living meaning. Dead forms, he may note, are always dangerous. If we still possessed the art and craft of ceremony, new forms might be evolved. It is remarkable that the whole essence of the ancient ritual not only does not contain any recognition of the one great motive force of modern civilisation, science, on which all progress, all wealth, and even all existence increasingly depend, but is actually a negation of it.

A really living symbolism is to be found in the "recognition" of the King by the people. This might form the nucleus of a representative ceremonial adequate to our times. Those present to "recognise" would be representative of every factor that helps to make the Empire, and in proportional numbers and prominence. Other countries have realised this opportunity. At every great State function in Germany a prominent place is assigned to the representatives of pure and applied science: the German mind realises that the wealth and well-being of the empire ultimately depend on science, and science alone. It is a pity that those responsible for the organisation of our ceremony sympathise so strongly with its archaic elements that they have not secured an adequate representation of the depositaries of modern knowledge, the true palladium of people and of empire.

A. E. Crawley.

\section{A $̈ R I A L ~ N A V I G A T I O N$ AND MECHANICS.}

$T$ HE exigencies of modern aëronautics combined with the uncertainties attaching to aëroplane flight are slowly but gradually directing attention to the necessity of researches and original papers of a highly specialised character, dealing with air pressures and the motions of bodies acted on by them. The question thus becomes imminent: Where should such investigations be published?

Until now no attempt has been made to make use of journals and transactions of societies publishing physical papers, and articles full of formulæ, diagrams, and tables have generally found their way into periodicals of a semi-popular or practical character, devoted to general aëronautical or engineering quiestions. The result has not always been satisfactory, and it has often been a question as to whether the printing of the formulæ or the reproduction of the diagrams has suffered the most. The insufficiency of the existing media for the publication of theoretical articles on aëronautics is, however, more clearly shown by asking the question: What is to be done with a manuscript of Ioo foolscap pages filled from beginning to end with long formulæ or diagrams? Further, whatever may be the drawbacks of the system of refereeing papers no doubt can exist as to the advantages of a ccllection of memoirs, all of which have been subjected to the judgment and criticism of external examiners.

The Government Blue-books contain exactly the lind of investigations to which these remarks apply, and the hope may therefore be expressed that these will in the future become a recognised medium for the publication of lengthy investigations which have been approved by the Government Committee.

The "Report" for I909-10 consists of (I) records of experiments performed at the National Physical Laboratory; (2) original papers by members of the committee and others; (3) abstracts of papers of a scientific character dealing with aëronautical problems.

Probably the features which possess the greatest interest for the large majority of readers are the abstracts and reports on the state of science with regard to specified subjects. The thirty-five pages of general abstracts do for aëronautical science what is done for physics and electrical engineering by "Science Abstracts." In order to make the collection more complete the compilers have included papers published some time ago; for example, abstract No. 8, deals with Turnbull's experiments, which were published in The Phvsical Review for 1907 .

Mr. F. J. Selby's special reports on the present state of knowledge regarding electrification of balloons and on papers by Ferber, Crocco, and Soreau, dealing with equations of motion and stability considerations, form a valuable contribution of a similar character. It is interesting to notice that several stability conditions in the papers referred to are defective, owing to the

1 Report of the Advisory Committee for Aëronautics for the year 1909rgro. Pp. rgr. (London: H.M. Stationery Office; Wyman and Sons, Ltd. ; Edinburgh : Oliver Boyd; Dublin: E. Ponsonby, Ltd., rgro.) Cd. 5282. Price $8 s$. $5 d$.

Interim Report on the work for the Year rgro-1r. Pp. 30. Cd. 5453. (London : H.M. Stationery Office ; Wyman and Sons, Ltd.; Edinburgh: Oliver Boyd; Dublin: E. Ponsonby, Ltd.) Price $1 s .2 d$.

Report on the Theory of a Stream Line past a Plane Barrier, and of the Discontinuity arising at the Edge, with the application of the theory to an Aëroplane, By Sir George Greenhill, F.R.S. Pp. $96+106$ figs. (Advisory Committee for Aëronautics Reports and Memoranda, No. I9.) (London: H.M. Stationerv Office; Wyman and Sons, Ltd.; Edinburgh: Oliver Boyd ; Dublin: E. Ponsonty, Ltd., rgro.) Price 55.

"The Aëroplane, an elementary text-book on the principles of dynamic flight." By T. O'B. Hubbard, J. H. Ledeboer, and C. C. Turner. Pp. xi r 128. (London: Longmans, Green, and Co., 19rr.) Price 2s. 6 d. net. "The Mechanics of the Earth's Atmosphere, a collection of Translations." By Cleveland Abbe. Third Collection. Pp. iv +6r7. (Washington, D.C. Smithsonian Institution, Igro.) (Smithsonian Miscellaneous Collections, Vol. li., No. 4 Hodgkins Fund.) 